\title{
Contrasting genetic diversity and differentiation of populations of two successional stages in a Neotropical pioneer tree (Eremanthus erythropappus, Asteraceae)
}

\author{
V.L.O. Freitas ${ }^{1}$, J.P. Lemos-Filho ${ }^{2}$ and M.B. Lovato ${ }^{3}$ \\ ${ }^{1}$ Setor de Recursos da Terra, Fundação Centro Tecnológico de Minas Gerais, \\ Belo Horizonte, MG, Brasil \\ ${ }^{2}$ Departamento de Botânica, Instituto de Ciências Biológicas, \\ Universidade Federal de Minas Gerais, Belo Horizonte, MG, Brasil \\ ${ }^{3}$ Departamento de Biologia Geral, Instituto de Ciências Biológicas, \\ Universidade Federal de Minas Gerais, Belo Horizonte, MG, Brasil
}

Corresponding author: M.B. Lovato

E-mail: lovatomb@icb.ufmg.br

Genet. Mol. Res. 7 (2): 388-398 (2008)

Received January 16, 2008

Accepted February 18, 2008

Published April 29, 2008

\begin{abstract}
Eremanthus erythropappus, commonly known as "candeia", is an abundant pioneer tree species, forming dense populations known as "candeial", but it is also found in forests at middle stages of succession. Trees from forests are bigger and occur in lower density than in the "candeial". The objectives of the present study were to investigate if the decrease in population density during successional process is accompanied by 1) changes in within-population genetic diversity, and 2) differentiation of populations. Eight populations, four of early successional stage ("candeial") and four of middle successional stages (forest), were analyzed with RAPD markers. The genetic diversity found was high compared to other tree species analyzed with RAPD markers. AMOVA revealed that most of the genetic variations of E. erythropappus were found within populations $(85.7 \%)$, suggesting that this species is predominantly outcrossing. The relatively low differentiation among the populations can be attributed to small distances among the populations analyzed $(0.2$ to $10.8 \mathrm{~km})$.
\end{abstract}


No indication that populations from middle successional habitats show lower genetic variation than populations from early successional stages was found. The percentage of polymorphic fragments (82.8 and $84.8 \%$ ) and the Shannon indexes (0.442 and 0.455) were similar in "candeial" and forest, respectively. These results suggest that if an increase in selection intensity occurred during succession, it did not result in a decrease in genetic diversity or that the selection effect was balanced by other factors, such as gene flow. Higher significant differentiation among E. erythropappus populations from "candeial" in relation to that among populations from forest was also not detected.

Key words: Asteraceae; "Candeia”; Eremanthus erythropappus; Genetic diversity; Pioneer species; Succession

\section{INTRODUCTION}

Succession is characterized by a change in species composition, where pioneers are followed by early successional species, and these by species of later successional stages (Whittaker, 1993). The increase in anthropogenic pressure on natural environments results in ecosystems with various stages of recovery, and so studies of succession are important in order to improve practices for ecosystem preservation, management, and restoration. The knowledge of genetic diversity changes during succession provides a fundamental basis for these practices.

During a successional process, some pioneer long-lived species can remain in the community even after temporal changes in species composition (Pluess and Stöcklin, 2004; Goulart et al., 2005; Litrico et al., 2005). These species provide an interesting model to study ecological and genetic changes that occur during succession. Several studies have found phenotypic differences between colonizer populations and populations that persist in more advanced stages of succession, similar to differences between pioneer and late successional species. Plants from later populations are on average bigger, with a higher competitive capacity (Gray, 1987; Bazzaz, 1996) and seeds with lower dispersion capacity (Peroni, 1994). However, it is not well established if during succession genetic changes within species also occur, but alterations in allelic frequencies are presumed to happen (Gray, 1987). The first studies found differences in genotypic frequencies in isozyme loci during succession (Hancock and Wilson, 1976). It is predicted that genetic diversity will be lower in persistent populations than in founder ones (Gray, 1987) due to certain genotypes being eliminated by selection during succession (Hancock and Wilson, 1976; Gray, 1987; Hartnett et al., 1987) or due to casual mechanisms, such as founder effects (Hartnett et al., 1987).

Eremanthus erythropappus (DC) MacLeish (Asteraceae), commonly known as "candeia", is an abundant pioneer tree species forming dense populations in fields and open pastures, known as "candeial" which establishes after forest perturbation. The "candeial" has low or no vertical structuring, and "candeia" is the dominant species, along with a few other species. During succession, the population size of E. erythropappus decreases, and "candeia" is found in middle successional habitats in forests in lower density (CETEC, 1996; Souza et al., 2007). The trees of the "candeial" are small (up to $10 \mathrm{~m}$ high), with an irregular and short 
trunk, whereas those from forests are bigger, with a long and cylindrical trunk (Pedralli, 1997). They are found in the States of Bahia, Minas Gerais, and Rio de Janeiro, Brazil. "Candeia" as a typical pioneer species has positive photoblastic anemochoric seeds which remain viable in the soil for a long time but have a low germination rate (CETEC, 1996). Flowering and fruiting occur from May to November, and its small purple flowers are visited by small bees (CETEC, 1996). This species has a great economic potential due to the qualities of its wood and also to its content of $\alpha$-bisabolol oil which is utilized in the pharmaceutical and cosmetic industries (Clementi, 1987). Due to its economical value, "candeia" is being submitted to intensive and disordered exploitation (Souza et al., 2007).

Here, we report the patterns of genetic variation among and within populations of E. erythropappus from "candeial" and from forest habitats located in two reserve areas, Ecological Station of Tripuí and the State Park of Itacolomi, Ouro Preto, Minas Gerais State, Brazil. Eight populations were analyzed in four areas, constituting four successional pairs of populations, each pair containing one "candeial" population (early successional) contiguous to one from the forest (middle successional). Using random amplified polymorphic DNA (RAPD) markers, we examined how genetic variation is partitioned within and among populations of E. erythropappus. In general, early successional species exhibit higher genetic divergence among their populations than do late-successional species (Hamrick and Godt, 1989; Nybom and Bartish, 2000; Nybom, 2004). In a similar way, it can be hypothesized that in a comparison within the same species, early successional populations ("candeial") could be more genetically differentiated than middle successional ones (forest). In addition, considering the great phenotypic differentiation among trees from "candeial" and forest, and reduction in population density during the successional process, we also hypothesized that populations from the forest have lower genetic variation due to competition pressure and/or genetic drift.

\section{MATERIAL AND METHODS}

\section{Sample design}

The populations used in this study were located within the native range of Eremanthus erythropappus in Minas Gerais State, Brazil, in two neighboring reserve areas: Ecological Station of Tripuí and the State Park of Itacolomi located from $20^{\circ} 22^{\prime} 30^{\prime \prime}$ to $20^{\circ} 30^{\prime} 00^{\prime \prime} \mathrm{S}$ and from $43^{\circ} 32^{\prime} 30^{\prime \prime}$ to $43^{\circ} 22^{\prime} 30^{\prime \prime} \mathrm{W}$. These areas have formations of Atlantic Forest and Cerrado (savanna vegetation) (Pedralli, 1997; Pedralli et al., 2000). The Ecological Station of Tripuí and the State Park of Itacolomi have a total area of 337 and 7543 ha, respectively.

In total, eight areas were sampled, constituting four successional pairs, each pair formed by two contiguous populations, one from "candeial" and another from forest. Three of these pairs were located in the Ecological Station of Tripuí and one pair in the State Park of Itacolomi (Table 1). The "candeial" was considered an early successional stage and the forest area, a middle successional stage. The mean density of E. erythropappus in the "candeial" and forest is 356.6 and 46.8 ind. ha ${ }^{-1}$, respectively (CETEC, 1996).

Twenty random individuals from each of eight populations, totaling 160 individuals, were marked and had their height and circumference at breast height measured. Recently, expanded leaves were collected from each individual and stored at $-70^{\circ} \mathrm{C}$ before DNA extraction. 


\section{DNA extraction and RAPD analysis}

Genomic DNA was extracted from approximately $0.4 \mathrm{~g}$ of young leaves using a modification of the cetyltrimethylammonium bromide protocol described by Ribeiro (1998). After visual quantification, by comparison with standard DNA concentrations, DNAs were diluted in TE buffer to a final concentration of $\approx 5 \mathrm{ng} / \mu \mathrm{L}$. Polymerase chain reaction was performed in $20 \mu \mathrm{L}$ total volume containing $10 \mathrm{mM}$ Tris- $\mathrm{HCl}, \mathrm{pH} 8.0,50 \mathrm{mM} \mathrm{KCl}, 2 \mathrm{mM} \mathrm{MgCl}, 0.1$ $\mathrm{mM}$ of each dNTP, 1 unit of Taq DNA polymerase, $0.25 \mu \mathrm{M}$ of primer and approximately 20 ng of genomic DNA. Amplifications of RAPDs were carried out in a PTC-100 ${ }^{\text {TM }}$ (M.J. Research, Inc.) thermocycler using the following polymerase chain reaction conditions: an initial denaturation step of $95^{\circ} \mathrm{C}$ for $1 \mathrm{~min}$, followed by 35 cycles each of $94^{\circ} \mathrm{C}$ for $10 \mathrm{~s}, 36^{\circ} \mathrm{C}$ for 1 $\min$, and $72^{\circ} \mathrm{C}$ for $2 \mathrm{~min}$ and a final extension step of $72^{\circ} \mathrm{C}$ for $7 \mathrm{~min}$. A negative control was included in each run, in which DNA was omitted, to verify the absence of contamination. Following amplification, the samples were subjected to electrophoresis, approximately $3 \mathrm{~h} \mathrm{(100}$ V), on a $1 \%$ agarose gel, made with $1 \mathrm{X}$ TBE buffer, stained with ethidium bromide, visualized by illumination with ultraviolet light and photographed for analysis. Molecular size of the fragments was estimated using a 100-bp ladder (Life Technologies).

From a pilot survey with 30 decamer primers from Operon Technologies Inc., 10 from Kit A (OPA) and 20 from Kit L (OPL), 10 were selected for the complete survey (OPA-10, OPL-01, OPL-02, OPL-04, OPL-07, OPL-08, OPL-11, OPL-13, OPL-14, OPL-19) after a detailed preliminary screening with three individuals, each one of a population that consistently revealed sharp and reproducible RAPD products (bands) over two independent runs. Furthermore, one individual was used as a standard marker, beside the 100-bp lader, for scoring bands and confirming consistent amplifications during the whole study.

\section{Data scoring and statistical analysis}

Gels were scored for the presence (1) or absence (0) of a band and a matrix of RAPD phenotypes was assembled. Only bands that showed a reproducible pattern and clearness were used for statistical analysis. One locus was considered polymorphic at the population level, if at least one individual showed or not the band $(95 \%)$. The diversity within populations was quantified by two indices: 1) the Shannon index $\left(\mathrm{H}_{\mathrm{O}}\right)$ and 2) the percentage of polymorphic bands. The Shannon index of diversity $\left(\mathrm{H}_{\mathrm{O}}\right)$ was estimated from the frequencies of the RAPD bands within each population and also over all populations. The equation used was: $H=-\Sigma p_{i} \log _{2} p_{i}$, where $p_{i}$ was the frequency of the presence or absence of the band (Lacerda et al., 2001; Goulart et al., 2005). The among-population diversity component was calculated as $\left(\mathrm{H}_{\mathrm{SP}}-\mathrm{H}_{\mathrm{POP}}\right) / \mathrm{H}_{\mathrm{SP}}$, where $\mathrm{H}_{\mathrm{SP}}$ is the total diversity, i.e., the diversity of all populations together and $\mathrm{H}_{\mathrm{POP}}$ the mean withinpopulation diversity value. The proportion within population was calculated as $\mathrm{H}_{\mathrm{POP}} / \mathrm{H}_{\mathrm{SP}}$.

We performed three different AMOVAs (Excoffier et al., 1992), based on Euclidean squared distances among individuals, with significance level evaluated after 16,000 random permutations. The first one, a one-level analysis, considered the variation among the eight populations. To test for differences in the level of genetic diversity between populations from early and middle successional stages, we used two two-level AMOVAs. The first one considered differences between the successional stages and differences among populations within the successional stages, without consideration of pair structure. The other AMOVA performed 
considered the differences among the successional pairs and the differences between populations within successional pairs, i.e., between the neighbor "candeial" and forest populations.

To test the hypothesis of "isolation by distance", a genetic distance matrix $\left(\phi_{\mathrm{ST}}\right.$ values), obtained by AMOVA procedures, was correlated with a geographical distance matrix by the Mantel test, and its significance was tested by a nonparametric permutation procedure.

\section{RESULTS}

Morphological data revealed that Eremanthus erythropappus individuals from forest were on average almost two times bigger than those from "candeial" in height as well the circumference at the breast height (Table 1). A considerable amount of genetic variation within and among populations of E. erythropappus was detected. One hundred and sixty unique RAPD banding patterns were observed, i.e., each individual had a unique RAPD phenotype. A total of 99 fragments were scored and $89.9 \%$ of these markers were polymorphic, and the number of polymorphic fragments scored per primer varied from 5 (OPL-13) to 13 (OPL-07) (Table 2).

\begin{tabular}{|c|c|c|c|c|}
\hline Population pair & Location & $\begin{array}{c}\text { Successional } \\
\text { stage }\end{array}$ & $\begin{array}{l}\mathrm{CBH} \\
(\mathrm{cm})\end{array}$ & $\begin{array}{l}\text { Height } \\
(\mathrm{m})\end{array}$ \\
\hline 1- Itacolomi-C & Itacolomi State Park & early & $38.3(8.1)$ & $4.8(0.9)$ \\
\hline 1- Itacolomi-F & Itacolomi State Park & middle & $69.1(26.5)$ & $9.9(1.8)$ \\
\hline 2- Trevo-C & Tripuí Ecological Station & early & $34.4(7.8)$ & $6.5(0.7)$ \\
\hline 2- Fortes-F & Tripuí Ecological Station & middle & $65.8(20.3)$ & $9.9(0.8)$ \\
\hline 3- Adão-C & Tripuí Ecological Station & early & $30.1(12.9)$ & $5.0(0.9)$ \\
\hline 3- Esperto-F & Tripuí Ecological Station & middle & $57.5(14.9)$ & $9.1(1.3)$ \\
\hline 4- Pomar-C & Tripuí Ecological Station & early & $30.8(16.7)$ & 4.7 (1.6) \\
\hline 4- Pomar-F & Tripuí Ecological Station & middle & $60.6(21.0)$ & $9.2(1.0)$ \\
\hline Early stage mean & & & $33.4(11.4)$ & $5.2(1.0)$ \\
\hline Middle stage mean & & & $63.2(20.7)$ & $9.5(1.2)$ \\
\hline
\end{tabular}

The capital letters following the population name correspond to "candeial" (C) and forest (F).

\begin{tabular}{|c|c|c|c|c|}
\hline Primer & Sequence $\left(5^{\prime} \rightarrow 3^{\prime}\right)$ & $\begin{array}{l}\text { Fragment size } \\
\text { range (bp) }\end{array}$ & $\begin{array}{l}\text { No. of polymorphic fragments/ } \\
\text { total No. of fragments }\end{array}$ & $\begin{array}{l}\text { Percent of polymorphic } \\
\text { fragments }\end{array}$ \\
\hline OPA-10 & GTGATCGCAG & $500-2000$ & $10 / 11$ & $90.9 \%$ \\
\hline OPL-01 & GGCATGACCT & $800-2000$ & $7 / 7$ & $100.0 \%$ \\
\hline OPL-02 & TGGGCGTCAA & $500-1200$ & $9 / 9$ & $100.0 \%$ \\
\hline OPL-04 & GACTGCACAC & $450-2000$ & $7 / 9$ & $77.8 \%$ \\
\hline OPL-07 & AGGCGGGAAC & $500-2000$ & $13 / 16$ & $81.3 \%$ \\
\hline OPL-08 & AGCAGGTGGA & $500-2000$ & $9 / 10$ & $90.0 \%$ \\
\hline OPL-11 & ACGATGAGCC & $350-1800$ & $11 / 11$ & $100.0 \%$ \\
\hline OPL-13 & ACCGCCTGCT & $450-1450$ & $5 / 7$ & $71.4 \%$ \\
\hline OPL-14 & GTGACAGGCT & $550-1650$ & $8 / 9$ & $88.9 \%$ \\
\hline OPL-19 & GAGTGGTGAC & $600-2000$ & $10 / 10$ & $100.0 \%$ \\
\hline Total & & & $89 / 99$ & $89.9 \%$ \\
\hline
\end{tabular}


There was a considerable variation among populations in their diversity indexes (Table 3 ). The percentage of polymorphic bands within populations ranged from 54.5 (Pomar-C) to $70.7 \%$ (Trevo-C and Fortes-F), and the Shannon indexes varied from 0.382 (Pomar-C) to 0.487 (Trevo-C). However, these variations were not associated with successional stages, with populations from early ("candeial") and middle successional (forest) stages exhibiting similar levels of genetic diversity. The percent of polymorphic fragments found in total "candeial" stage was $82.8 \%$ and in forest stage was $84.8 \%$, values not significantly different $(\mathrm{P}=0.747)$ as with differences among successional pairs $(\mathrm{P}=0.057)$. The successional stages also did not differ in relation to the Shannon index, with mean of populations from "candeial" equal to 0.442 and mean of populations from forest equal to $0.455(\mathrm{P}=0.641)$, and also the values of population pairs were not significantly different $(\mathrm{P}=0.087)$. In fact, it can be observed that in two successional pairs, Esperto-C/Adão-F and Pomar-C/Pomar-F, the forest populations exhibit higher Shannon index values than the respective population from "candeial", and in the two remaining pairs, Itacolomi-C/Itacolomi-F and Trevo-C/Fortes-F, the relation is inverse, with the "candeial" population having higher values than the forest one (Table 3 ). The test of homogeneity of molecular variance (HOMOVA) also agreed with the Shannon index, indicating that populations exhibit different levels of molecular variance ( $\mathrm{bp}=0.704 ; \mathrm{P}<0.001)$, but that these differences also did not have any relation to successional stages, since early and middle succession populations did not show different levels of molecular variance $(\mathrm{P}=0.234)$.

\begin{tabular}{|c|c|c|c|}
\hline Successional stage & Population & $\%$ of polymorphic fragments & Shannon index $\left(\mathrm{H}_{\mathrm{o}}\right)$ \\
\hline \multirow[t]{5}{*}{ Early } & Itacolomi-C & $67.7 \%$ & 0.479 \\
\hline & Trevo-C & $70.7 \%$ & 0.487 \\
\hline & Adão-C & $64.6 \%$ & 0.421 \\
\hline & Pomar-C & $54.5 \%$ & 0.382 \\
\hline & Mean & $64.4 \%$ & 0.442 \\
\hline \multirow[t]{5}{*}{ Middle } & Itacolomi-F & $61.6 \%$ & 0.470 \\
\hline & Fortes-F & $70.7 \%$ & 0.484 \\
\hline & Esperto-F & $65.7 \%$ & 0.44 \\
\hline & Pomar-F & $63.6 \%$ & 0.424 \\
\hline & Mean & $65.4 \%$ & 0.455 \\
\hline
\end{tabular}

To allow the partitioning of the RAPD variation within and among populations, the Shannon index and AMOVA were used. The Shannon index indicated that, on average, $17.8 \%$ of the variation was due to differences between populations (values not shown). The overall AMOVA showed a broad agreement with the Shannon index, with $14.3 \%$ of variation attributed to variation among populations (Table 4). Mantel tests were performed to examine the correlation between genetic and geographical distance. The test considering all populations showed no significance. However, another Mantel test including only comparisons between more distant populations, i.e., populations from Tripuí with populations from Itacolomi (geographical distances ranging from 7,800 to $10,300 \mathrm{~m}$ ) revealed one positive and significant correlation $(\mathrm{r}=0.6267, \mathrm{P}=0.029)$ between geographical and genetic distances, indicating that genetic diversity increased with increased geographical distance. Comparisons among populations geographically close (300 to $3,000 \mathrm{~m}$ apart), i.e., within of the same reserve, did not indicate a significant correlation. 


\begin{tabular}{|c|c|c|c|c|c|}
\hline Source of variation & d.f. & Sum of squares & Variance components & $\%$ of total variance & $\mathrm{P}$ \\
\hline \multicolumn{6}{|l|}{ All populations } \\
\hline Among populations & 7 & 323.17 & 1.77 & $14.3 \%$ & $<0.001$ \\
\hline Within populations & 152 & 1618.95 & 10.65 & $85.7 \%$ & \\
\hline \multicolumn{6}{|l|}{ Successional pairs } \\
\hline Among successional pairs & 3 & 161.89 & 0.34 & $2.7 \%$ & 0.108 \\
\hline Between populations/within pairs & 4 & 161.27 & 1.48 & $11.9 \%$ & $<0.001$ \\
\hline Within populations & 152 & 1618.95 & 10.65 & $85.4 \%$ & $<0.001$ \\
\hline \multicolumn{6}{|l|}{ Successional stages } \\
\hline Among successional stages & 1 & 38.78 & -0.11 & $-0.9 \%$ & 0.792 \\
\hline Among populations/within stages & 6 & 284.39 & 1.84 & $14.8 \%$ & $<0.001$ \\
\hline Within populations & 152 & 1618.95 & 10.65 & $86.0 \%$ & $<0.001$ \\
\hline
\end{tabular}

d.f. $=$ degrees of freedom.

To evaluate the effect of successional stages on genetic structure, we performed two different AMOVAs, with two different groupings (Table 4). The first one considered two groups, early and middle succession, and showed that populations from two stages do not diverge $(-0.9 \%$ of variance due to differences between the stages, $\mathrm{P}=0.79)$. This result indicated that successional stage did not explain any variation among populations. However, these analyses also indicated that within each stage, the populations are genetically divergent ( $14.8 \%$ of variation is due to differences among populations within stages $(\mathrm{P}<$ 0.001). Another AMOVA indicated that the successional pairs are not different, but that the population within pairs, i.e., populations located near to each other, one from "candeial" and other from forest are genetically different, with $11.9 \%$ of variation attributed to differences between populations within pairs $(\mathrm{P}<0.001)$. Together, these AMOVAs (Table 4) and the pair-wise differences between populations (Table 5) indicate that all populations are different from each other, but the differences are not related to successional stage. The populations from "candeial" are not more divergent among themselves $\left(\phi_{\mathrm{ST}}\right.$ "candeial" $\left.=0.152 \pm 0.033\right)$ than are the forest populations among themselves $\left(\phi_{\mathrm{ST}}\right.$ forest $=0.139 \pm 0.052)$, with no significant difference $(\mathrm{P}=0.604, t$-test $)$.

Table 5. Pairwise comparisons of $\phi_{\mathrm{ST}}$ values among populations of Eremanthus erythopappus of early and middle successional stages, based on RAPD markers.

\begin{tabular}{|c|c|c|c|c|c|c|c|c|}
\hline \multirow[t]{2}{*}{ Populations } & \multicolumn{4}{|c|}{ Early } & \multicolumn{4}{|c|}{ Middle } \\
\hline & Itacolomi-C & Trevo-C & Adão-C & Pomar-C & Itacolomi-F & Fortes-F & Esperto-F & Pomar-F \\
\hline \multicolumn{9}{|l|}{ Early } \\
\hline Itacolomi-C & - & & & & & & & \\
\hline Trevo-C & $0.126^{*}$ & - & & & & & & \\
\hline Adão-C & $0.170^{*}$ & $0.186^{*}$ & - & & & & & \\
\hline Pomar-C & $0.106^{*}$ & $0.142 *$ & $0.184^{*}$ & - & & & & \\
\hline \multicolumn{9}{|l|}{ Middle } \\
\hline Itacolomi-F & $0.124^{*}$ & $0.153 *$ & $0.151^{*}$ & $0.107 *$ & - & & & \\
\hline Fortes-F & $0.106^{*}$ & $0.113^{*}$ & $0.186^{*}$ & $0.138^{*}$ & $0.089^{*}$ & - & & \\
\hline Esperto-F & $0.186^{*}$ & $0.164 *$ & $0.143^{*}$ & $0.178^{*}$ & $0.187 *$ & $0.201^{*}$ & - & \\
\hline Pomar-F & $0.123^{*}$ & $0.143^{*}$ & $0.096^{*}$ & $0.109^{*}$ & $0.073^{*}$ & $0.126^{*}$ & $0.157^{*}$ & - \\
\hline
\end{tabular}

$* \mathrm{P}<0.001$. 


\section{DISCUSSION}

\section{Diversity and genetic structure of Eremanthus erythropappus}

The diversity of populations of Eremanthus erythropappus can be considered high compared with other tree species from Brazil analyzed with RAPD markers. The Shannon indexes ( 0.382 to 0.487$)$ were higher than in Plathymenia reticulata ( 0.301 to 0.367 ; Lacerda et al., 2001), Mabea fistulifera (0.383 and 0.405; Goulart et al., 2005) and Hymenaea courbaril and $H$. stigonocarpa which showed average diversity of populations of 0.301 and $0.321\left(\mathrm{H}_{\mathrm{POP}}\right)$, respectively (Brandão, 2002). The percentage of polymorphic fragments found in populations of E. erythropappus (54.5 to 70.7\%) was also higher than in populations of $P$. reticulata (41.7 to 55.6\%; Lacerda et al., 2001), M. fistulifera (49.0 to 56.0\%; Goulart et al., 2005), H. courbaril (37.7 to 47.8\%), and H. stigonocarpa (44.1 to $48.5 \%$ ) (Brandão, 2002). On the other hand, the diversity values found here are similar to that found in two other populations of E. erythropappus of other sites (Shannon indexes $=0.45$ and 0.49 ; Estopa et al., 2006), which suggests that high diversity is a characteristic of this species.

Most of the genetic variation of E. erythropappus was found within populations (85.7\%), as it is typical for outcrossing, long-lived species (Hamrick and Godt, 1989; Nybom and Bartish, 2000; Nybom, 2004). Sporophytic self incompatibility system is common in the Asteraceae family (see Ferrer et al., 2004), a mechanism that prevents selfing and biparental inbreeding (Charlesworth and Charlesworth, 1987). In fact, Moura (2005) analyzing progenies of E. erythropappus with isozyme markers found that it is an outcrossing species. In addition, we observed small bees visiting flowers of E. erythropappus. Furthermore, among-population differentiation $\left(\phi_{\mathrm{ST}}=0.143\right)$ is not high if compared with the mean values reported in studies with RAPD markers for species with the same life history traits, considering outcrossing breeding system $\left(\phi_{\mathrm{ST}}=0.27\right)$, long-lived $\left(\phi_{\mathrm{ST}}\right.$ $=0.25)$ and early successional stage $\left(\phi_{\mathrm{ST}}=0.37\right)$ (Nybom, 2004). However, maximum geographical distance between populations analyzed with RAPD markers has a strong positive effect on genetic differentiation found between populations (Nybom and Bartish, 2000; Nybom 2004). The maximum geographical distances among populations studied here $(10.8 \mathrm{~km})$ are much lower than the mean of maximum distances among populations $(956 \mathrm{~km})$ in studies reviewed by Nybom (2004). This could explain in part the comparably low value of among-population variation in E. erythropappus. One fact that corroborates this suggestion is that a positive correlation was found between genetic distance and geographical distance considering populations more distant, i.e., populations from Itacolomi in relation to those from Tripuí (above $7.8 \mathrm{~km}$ ). This suggests that gene flow among populations of E. erythropappus is dependent on geographical distance. In fact, this also was suggested by Estopa et al. (2006) who found a value of differentiation among $E$. erythropappus populations a little higher $\left(\mathrm{G}_{\mathrm{ST}}=0.21\right)$ than that found in the present study, but also with maximum geographical distance among populations greater $(37 \mathrm{~km})$ than among the populations studied here. In spite of differentiation among overall populations not being high, it must be noted that even populations spatially very close, i.e, of the same reserve, exhibited considerable genetic structure (mean $\phi_{\mathrm{ST}}=0.151$ among populations from Tripuí). This suggests that the putative pollinator of E. erythropappus (small bees) 
exhibits small flight distance, allowing crossings to occur mainly between near trees, restricting gene flow by pollen.

\section{Comparison of diversity and genetic structure among Eremanthus erythropappus populations from early and middle successional stages}

We found no indication that populations from middle successional stage (forest) show lower genetic variation than populations from early successional stage ("candeial"), in opposition to our previous hypothesis. The percentage of polymorphic fragments in the two community types was high and did not differ statistically, 82.8 and $84.8 \%$ ("candeial" and forest, respectively). The populations from "candeial" also did not differ in relation to genetic variation evaluated by the Shannon index $($ mean $=0.442)$ from the populations from forest $($ mean $=0.455)$. The two indices used to estimate within population diversity in the two successional stages were concordant, and none indicated differences in degree of genetic diversity between populations from "candeial" and populations from forest. These results do not support the hypothesis that the selection of genotypes during succession leads to genetic depletion (Gray, 1987), but they are in accordance with several other studies indicating that populations maintain equal levels of intra-populational genetic diversity during succession (Aarssen and Turkington, 1985; Hartnett et al., 1987; Peroni, 1994; Pluess and Stöcklin, 2004; Solé et al., 2004; Goulart et al., 2005; Raffl et al., 2006). These results suggest that if an increase in selection intensity occurred during succession it did not result in a decrease in genetic diversity or that the selection effect was balanced by other factors, such as gene flow. Earlysuccessional species in general exhibit a higher percentage of genetic diversity among populations than late-successional species (Hamrick and Godt, 1989; Nybom 2004). However, in evaluating within same species, we did not detect higher significant differentiation among $H$. erythropappus populations from an early successional stage in relation to that among populations from middle successional one. Differentiation among colonizing populations depends on the type of colonization (one versus several source populations) and the amount of post-colonizing recurrent gene flow, as reviewed by Raffl et al. (2006). Considering the spatial proximity among "candeial" populations studied here, gene flow among them can be considerable, and thus "candeial" populations must receive genes from different sources (populations).

Although we did not find genetic differences associated with successional status of habitats of E. erythropappus, the great morphological differences among trees of "candeial" and forest must be noted. RAPD markers have been generally reported to be neutral markers (Brunell and Whitkus, 1997; Heaton et al., 1999), and here we did not analyze genetic differences in relation to morphological characters among the two successional stages. The morphological differences can be due to genetic differences and/or phenotypic plasticity. To conclude about the relative influence of these two factors, it is necessary to evaluate progenies from two successional stages in a common garden experiment.

\section{ACKNOWLEDGMENTS}

Research supported by the Fundação de Amparo à Pesquisa do Estado de Minas Gerais (FAPEMIG). J.P. Lemos-Filho received a research fellowship from the Conselho Nacional de Desenvolvimento Científico e Tecnológico (CNPq/Brazil). We also thank the Instituto Estadual de Floresta (IEF) for the facilities for sampling populations. 


\section{REFERENCES}

Aarssen LW and Turkington R (1985). Within-species diversity in natural populations of Holcus lanatus, Lolium perenne, and Trifolium repens from four different-aged pastures. J. Ecol. 73: 869-886.

Bazzaz FA (1996). Plants in changing environments: linking physiological, population, and community ecology. Cambridge University Press, Cambridge.

Brandão RL (2002). Variabilidade e estrutura genética de duas espécies vicariantes, Hymenaea courbaril (jatobá da mata) e H. stigonocarpa (jatobá do cerrado). M.SC thesis, Universidade Federal de Minas Gerais, Belo Horizonte.

Brunell MS and Whitkus R (1997). RAPD marker variation in Eriastrum densifolium (Polemoniaceae): implications for subspecific delimitation and conservation. Syst. Bot. 22: 543-553.

CETEC (1996). Ecofisiologia da Candeia. SAT/CETEC, Belo Horizonte.

Charlesworth D and Charlesworth B (1987). Inbreeding depression and its evolutionary consequences. Ann. Rev. Ecol. Syst. 18: 237-268.

Clementi G (1987). Alpha-bisabolol natural: an antiphlogist active principle derived from nature. Dragoco Perfumes e Aromas, São Paulo. (Technical Information).

Estopa RA, Souza AM, Moura MCO, Botrel MCG, et al. (2006). Diversidade genética em populações naturais de candeia (Eremanthus erythropappus DC. MacLeish). Sci. Forestalis 70: 97-106.

Excoffier L, Smouse PE and Quattro JM (1992). Analysis of molecular variance inferred from metric distances among DNA haplotypes: application to human mitochondrial DNA restriction data. Genetics 131: 479-491.

Ferrer MM, Eguiarte LE and Montana C (2004). Genetic structure and outcrossing rates in Flourensia cernua (Asteraceae) growing at different densities in the South-western Chihuahuan Desert. Ann. Bot. 94: 419-426.

Goulart MF, Ribeiro SP and Lovato MB (2005). Genetic, morphological and spatial characterization of two populations of Mabea fistulifera Mart. (Euphorbiaceae), in different successional stages. Braz. Arch. Biol. Techn. 48: 275-284.

Gray AJ (1987). Genetic change during succession in plants. In: Colonization, succession and stability (Gray AJ, Crawley MJ and Edwards PJ, eds.). Symposium of the British Ecological Society, Blackwell, Oxford, 273-293.

Hamrick JL and Godt MJW (1989). Allozyme diversity in plant species. In: Plant population genetics, breeding and genetic resources (Brown AHD, Clegg MT, Kahler AL and Weir BS, eds.). Sinauer Associates, Sunderland, 43-63.

Hancock JF and Wilson RE (1976). Biotype selection in Erigeron annuus during old field succession. Bull. Torrey Bot. Club. 103: 122-125.

Hartnett DC, Hartnett BB and Bazzaz FA (1987). Persistence of Ambrosia trifida populations in old fields and responses to successional changes. Am. J. Bot. 74: 1239-1248.

Heaton HJ, Whitkus R and Gómez-Pompa A (1999). Extreme ecological and phenotypic differences in the tropical tree Chicozapote (Manilkara zapota (L.) P. Royen) are not matched by genetic divergence: a random amplified polymorphic DNA (RAPD) analysis. Mol. Ecol. 8: 627-632.

Lacerda DR, Acedo MD, Lemos-Filho JP and Lovato MB (2001). Genetic diversity and structure of natural populations of Plathymenia reticulata (Mimosoideae), a tropical tree from the Brazilian Cerrado. Mol. Ecol. 10: 1143-1152.

Litrico I, Ronfort J, Verlaque R and Thompson JD (2005). Spatial structure of genetic variation and primary succession in the pioneer tree species Antirhea borbonica on La Reunion. Mol. Ecol. 14: 1575-1584.

Moura MCO (2005). Distribuição da variabilidade genética em populações naturais de Eremanthus erythropappus (DC.) MacLeish por isoenzimas e RAPD. Doctoral thesis, Universidade Federal de Lavras, Lavras.

Nybom H (2004). Comparison of different nuclear DNA markers for estimating intraspecific genetic diversity in plants. Mol. Ecol. 13: 1143-1155.

Nybom H and Bartish IV (2000). Effects of life history traits and sampling strategies on genetic diversity estimates obtained with RAPD markers in plants. Plant Ecol. Evol. Syst. 3: 93-114.

Pedralli G (1997). Estrutura diamétrica, vertical e análise do crescimento da "candeia" (Vanillosmopsis erythropappa Sch. Bip.) na Estação Ecológica do Tripuí, Ouro Preto, MG. Rev. Árvore 21: 301-306.

Pedralli G, Teixeira MCB, Freitas VLO, Meyer ST, et al. (2000). Florística e fitossociologia da Estação Ecológica do Tripuí, Ouro Preto-MG. Cienc. Agrotec. 24: 103-136.

Peroni PA (1994). Seed size and dispersal potential of Acer rubrum (Aceraceae) samaras produced by populations in early and late successional environments. Am. J. Bot. 81: 1428-1434.

Pluess AR and Stöcklin J (2004). Population genetic diversity of the clonal plant Geum reptans (Rosaceae) in the Swiss Alps. Am. J. Bot. 91: 2013-2021.

Raffl C, Schonswetter P and Erschbamer B (2006). 'Sax-sess' - genetics of primary succession in a pioneer species on two parallel glacier forelands. Mol. Ecol. 15: 2433-2440.

Ribeiro SP (1998). The role of herbivory in Tabebuia spp. Life history and evolution. PhD thesis, Imperial College at 
Silwood Park, University of London, London.

Solé M, Durka W, Eber S and Brandl R (2004). Genotypic and genetic diversity of the common weed Cirsium arvense (Asteraceae). Int. J. Plant Sci. 165: 437-444.

Souza AL, Oliveira MLR, Silva EF and Coelho DJS (2007). Caracterização fitossociológica em áreas de ocorrência natural de candeia (Eremanthus erythropapus (D.C.) MacLeish). Rev. Árvore 31: 667-677.

Whittaker RJ (1993). Plant population patterns in a glacier foreland succession: pioneer herbs and later-colonizing shrubs. Ecography 16: 117-136. 